\title{
Urban Planning Insights from Tree Inventories and Their Regulating Ecosystem Services Assessment
}

\author{
Luca Rossi $^{1}$, Maria Elena Menconi ${ }^{1}\left(\mathbb{D}\right.$, David Grohmann $^{1, *}{ }^{\oplus}$, Antonio Brunori ${ }^{2}{ }^{\oplus}$ and David J. Nowak ${ }^{3}$ \\ 1 Department of Agricultural, Food and Environmental Sciences, University of Perugia, Via Borgo XX Giugno, \\ 74, 06121 Perugia, Italy; luca.rossi2092@gmail.com (L.R.); mariaelena.menconi@unipg.it (M.E.M.) \\ 2 PEFC Italia, Via Pietro Cestellini, 17/Int. 6, 06135 Perugia, Italy; info@pefc.it \\ 3 United States Department of Agriculture, Forest Service, Northern Research Station, 5 Moon Library \\ SUNY-ESF, Syracuse, NY 13210, USA; david.nowak@usda.gov \\ * Correspondence: david.grohmann@unipg.it
}

Citation: Rossi, L.; Menconi, M.E.; Grohmann, D.; Brunori, A.; Nowak, D.J. Urban Planning Insights from Tree Inventories and Their Regulating Ecosystem Services Assessment. Sustainability 2022, 14, 1684. https:// doi.org/10.3390/su14031684

Academic Editors: Carlo Bibbiani and Marco Bovo

Received: 22 December 2021

Accepted: 29 January 2022

Published: 1 February 2022

Publisher's Note: MDPI stays neutral with regard to jurisdictional claims in published maps and institutional affiliations.

Copyright: (C) 2022 by the authors. Licensee MDPI, Basel, Switzerland. This article is an open access article distributed under the terms and conditions of the Creative Commons Attribution (CC BY) license (https:// creativecommons.org/licenses/by/ $4.0 /)$.

\begin{abstract}
With the uncertainties that our societies are living with (the COVID-19 pandemic and climate change), it becomes essential to provide urban planners and decision-makers with state-of-theart and user-friendly methodologies to incorporate ecosystem service considerations into their designs for resilient cities. In this regard, urban forests play a crucial role. The quantification of the ecosystem services is geo-specific and needs studies in different urban contexts. At this scope, we evaluated the urban forest of a neighborhood of a densely built-up Italian city (Perugia) with a low level of urban greenery management and with a tree inventory still in progress. Furthermore, we defined a tool helpful in tree-planting decisions and management. This paper involves citizens in field research for trees inventory. Then, it uses i-Tree Eco to evaluate four ecosystem services (carbon storage and sequestration, pollution removal, and runoff avoided) provided by 373 inventoried urban trees belonging to 57 species. Our results show that Italian Municipal tree inventories do not adequately represent their urban forest and that citizens' participation provides a cost-effective method for integrating field data. Finally, the paper develops an easy tool helping local administrations enhance the ecosystem services provisions in urban green design.
\end{abstract}

Keywords: Mediterranean urban forest; urban green system; i-Tree Eco; urban decision making; citizen science; carbon sequestration; pollution removal; carbon storage; runoff avoided; structural value

\section{Introduction}

In 2050, around $68 \%$ of the world's population will live in urban areas, up from the current estimate of 55\% [1], and cities need to increase their resilience to respond to numerous uncertainties (increment of inhabitants, the COVID-19 pandemic, climate change, etc.). To achieve this aim, many scholars evaluated that nature inside cities provides multiple ecosystem services. The Millennium Ecosystem Assessment [2] described ecosystem services as "the benefits people obtain from ecosystems" (p.38), and divided them into supporting, provisioning, regulating, and cultural services. In the urban landscape, trees are essential elements covering $26.5 \%$ of urban areas globally, and they provide benefits to the citizens belonging to the four categories of MEA [3]. Concerning the regulating services, urban forests sequester carbon, release oxygen [4], regulate local climate [5], particularly heat islands [6-8], reduce the speed of stormwater runoff [9], and help control air and water pollution [10].

Nevertheless, urban tree cover has been declining recently, driven by competition for land in densely built-up cities [11]. In this context, public and political advocacy for urban forest conservation and maintenance could be improved by quantifying the ecosystem services provided by urban trees [12]. Many scholars have researched this issue [6,13-15], improving the understanding and appreciation of the numerous benefits that urban forests 
can cater to, but the results are geo-specific and depend on the urban morphology [8]. Therefore, there is a need for more studies in different urban contexts.

Furthermore, local administrators struggle to define practical rules or suggestions starting from the results regarding local vegetation assessment and the quantification of the service it provides [16]. In this regard, some scholars have developed tools dedicated to enhancing particular ecosystem services, such as urban heat mitigation $[8,17,18]$, stormwater management [19], and carbon stock [20]. Nevertheless, there is a lack of accessible tools to combine different ecosystem services and support decisions for urban green design, offering variable results varying the demanded services.

\subsection{Dataset Review of the Urban Forest Inventories of Italian Cities}

The Italian Law 10/2013, "Rules for the development of urban green spaces", requires that all Italian municipalities with over 15,000 inhabitants have an inventory of their trees in public green areas [21]. A successive law decree [22] has organized the inventory into three levels. The first level is mandatory for all the municipalities and asks for general information on the urban public green areas (their identification, localization, and dimensional characteristic). Generally, this first level is used by local administrators to define the tenders for maintenance contractors. The second level is mandatory for the cities with more than 15,000 inhabitants and asks for information on every tree inside the areas belonging to the first level (e.g., localization, genus, species, tree's characteristics, dimensions, and health). The third level is not mandatory and asks for information on other elements of the public green areas, such as details on shrubs, herbaceous covers, furniture, and equipment.

Since 2000, the Italian National Statistical Institute has acquired yearly data about urban greenery in 110 district capitals and metropolitan cities [23]. Since 2013, these data have also monitored the first two levels of the urban forest inventories (Table 1).

Table 1. The monitoring results regarding the urban forest inventories in Italian district capitals and metropolitan cities (31 December 2020).

\begin{tabular}{ccc}
\hline \multirow{2}{*}{ Percentage of Urban Forest Inventory Implemented } & First-Level & Second-Level \\
\cline { 2 - 3 } & $\mathbf{\%}$ & $\mathbf{\%}$ \\
\hline for the whole municipal green area & 47 & 33 \\
partial/in progress & 44 & 53 \\
total & 91 & 86 \\
\hline Inventories using georeferenced data & $\%$ & $\%$ \\
for the whole municipal green area & 31 & 31 \\
partial/in progress & 36 & 32 \\
total & 65 & 63 \\
within a geographical information system & 25 & \\
\hline
\end{tabular}

The table shows some issues in Italian urban tree inventories. Only a few municipalities use Geographical Information Systems (25\%), and many of them currently do not comply with the provisions of the law (only $31 \%$ of the cities have completed their georeferenced urban forest inventory, as required by law).

Furthermore, the Italian legislation requires investigation of the consistency of trees only in public urban green areas [23]. At the same time, various studies [24,25] have indicated the breakdown between evaluation and planning of public and private green spaces as one of the main barriers to an effective ecosystem services assessment in urban contexts.

Considering all these limitations, Italian municipalities need rules to improve the efficiency of the field research, software to evaluate the provided ecosystem services, field research to enhance their knowledge about urban greenery in public and private areas, and easy tools to help in urban green areas design. 


\section{2. i-Tree Eco to Assess Ecosystem Services}

Various software and frameworks have been developed (i.e., ARIES [26], Co\$ting Nature [27], LUCI [28], InVEST [29], WaterWorld [30], and i-Tree [31]) to assess the ecosystem services provided by vegetation.

This study used i-Tree, a suite of freely available software tools developed by the USDA Forest Service through a collaborative public-private partnership. First released in 2006, i-Tree has grown to include various tools used globally and encompass trees in all contexts (urban and rural) [31]. In particular, we choose the i-Tree Eco tool as it has become an international standard in assessing ecosystem services and economic values derived specifically from urban trees. Numerous studies have been conducted to validate this tool through case study applications $[20,32,33]$ and comparison and synergy with other tools such as allometric equations or direct measurements [34-38]. At first, i-Tree Eco has been extensively applied in the USA [39-41]; since 2010, it has been widely used in other countries and various climatic regions $[32,35,37,42,43]$, and, in recent years, its use has also been spreading in southern Europe/Mediterranean contexts [33,44,45].

i-Tree Eco uses a five-step workflow (structure, function, service, benefits, and economic value) following the relationship between biodiversity, ecosystem function, and human well-being, known as "service cascades", to assess ecosystem services values. The structure contains the basic information on the physical forest resource (i.e., number of trees, species composition, tree sizes, locations, leaf area, etc.). Various tree functions (i.e., gas exchange and tree growth) are estimated from the structure data and local weather data. These functions are then converted to multiple services (carbon storage, carbon sequestration, air pollution removal, and avoided runoff) based on other local data (i.e., pollution concentrations). These services are then turned into benefits (i.e., cleaner air and impacts on human health), and, finally, the benefits are converted to values based on various economic procedures [31]. Detailed methods and equations are given in Nowak [31].

Generally, scholars use i-Tree Eco in urban contexts to define urban green growth models [40], to assess a single ecosystem service as carbon storage [20], or air quality's improvement [35,37], to evaluate the ecosystem services provided by urban parks [32,42], or to compare urban green designs in ecosystem service provision [33]. However, for politicians and urban planners to consider the value of tree-planting in their daily decisions, there is a lack in the development of tools that are easy to use $[8,43]$.

Based on these considerations and to respond to the needs of the Italian municipalities discussed in the previous section, this paper uses i-Tree Eco to evaluate the ecosystem services provided by the urban forest of a densely populated neighborhood of an Italian city (Perugia). The goals of the research are (i) evaluating the effectiveness of citizens involvement in field research to realize tree inventories, (ii) evaluating the ecosystem services provided by urban trees in Mediterranean urban private and public areas of central Italy that are densely built-up, and (iii) developing an easy tool usable in decision support for urban green system planning and management able to strengthen the regulating ecosystem services.

\section{Materials and Methods}

\subsection{Study Area}

The study area is a densely populated neighborhood of Perugia (a medium-sized municipality in central Italy), covering a surface of 475.5 ha and located at the end of one of the built-up branches of the city (Figure 1).

There are 11,988 inhabitants, with a relatively high population density of 2524 people per $\mathrm{km}^{2}$ [46]. There are many industrial buildings and companies and heavy car traffic. The study area has a limited number of public green areas, and the urban green areas are mainly private or marginal ones. Furthermore, the intense real estate development pressure reduces the availability of open spaces to be used as new green areas. For this reason, it also increases the need to enhance the ecosystem services provided by the currently available ones. 


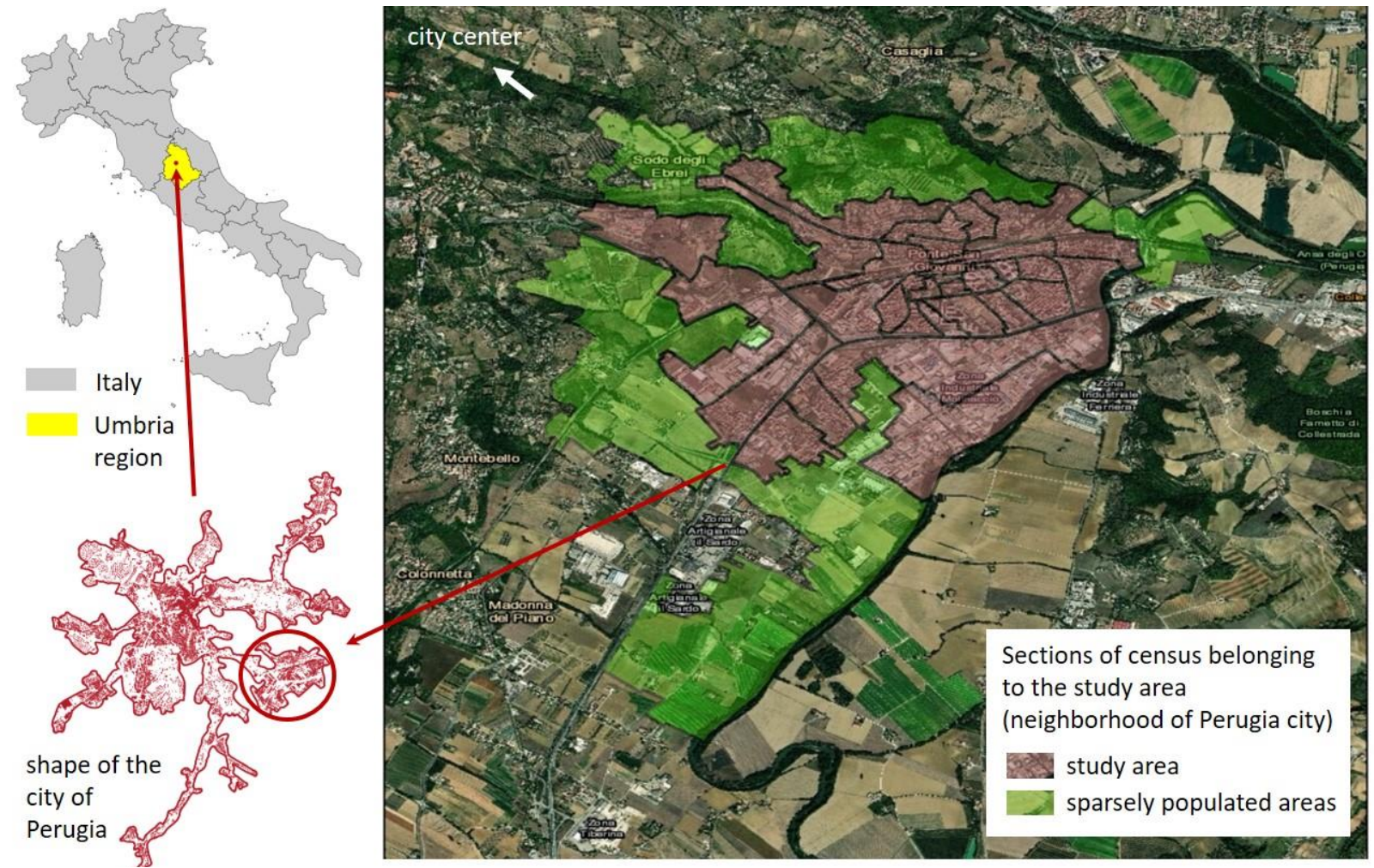

Figure 1. Study area. The neighborhood has a few sections sparsely populated that we did not consider in this study.

The study area is in a temperate zone with dry and hot summers. January is the coldest month, with an average temperature of $4.2{ }^{\circ} \mathrm{C}$; the hottest month is July, with an average temperature of $23^{\circ} \mathrm{C}$. The annual average temperature is around $13^{\circ} \mathrm{C}$. Annual precipitation is generally between 800 and $900 \mathrm{~mm}$ with rare snowfalls.

With high population density, air pollution is a crucial topic. $\mathrm{CO}, \mathrm{O}_{3}$, and $\mathrm{SO}_{2}$ concentrations are below the legal limit; $\mathrm{NO}_{2}$ concentrations are higher than those in spring, autumn, and winter $\left(47 \mu \mathrm{g} \mathrm{m}^{-3}\right)$. $\mathrm{PM}_{2.5}$ concentration is slightly under the limit during spring, summer, and autumn seasons, but winter values are almost double the legal limit (up to $70 \mu \mathrm{g} \mathrm{m}^{-3}$ ) [47].

\subsection{Steps of the Method}

Our method consists of six steps: (1) public dataset collection concerning weather data, pollution concentrations, and urban morphology; (2) participatory training meetings involving citizens; (3) definition of the plots object of field research; (4) data collection of urban greenery by citizens; (5) ecosystem service assessment; and (6) development of a geo-specific tool for supporting (6.1) tree-planting decisions to enhance ecosystem services provision and (6.2) economic evaluations differentiated by species in the definition of taxations linked to trees damaged or cut down (Figure 2). 


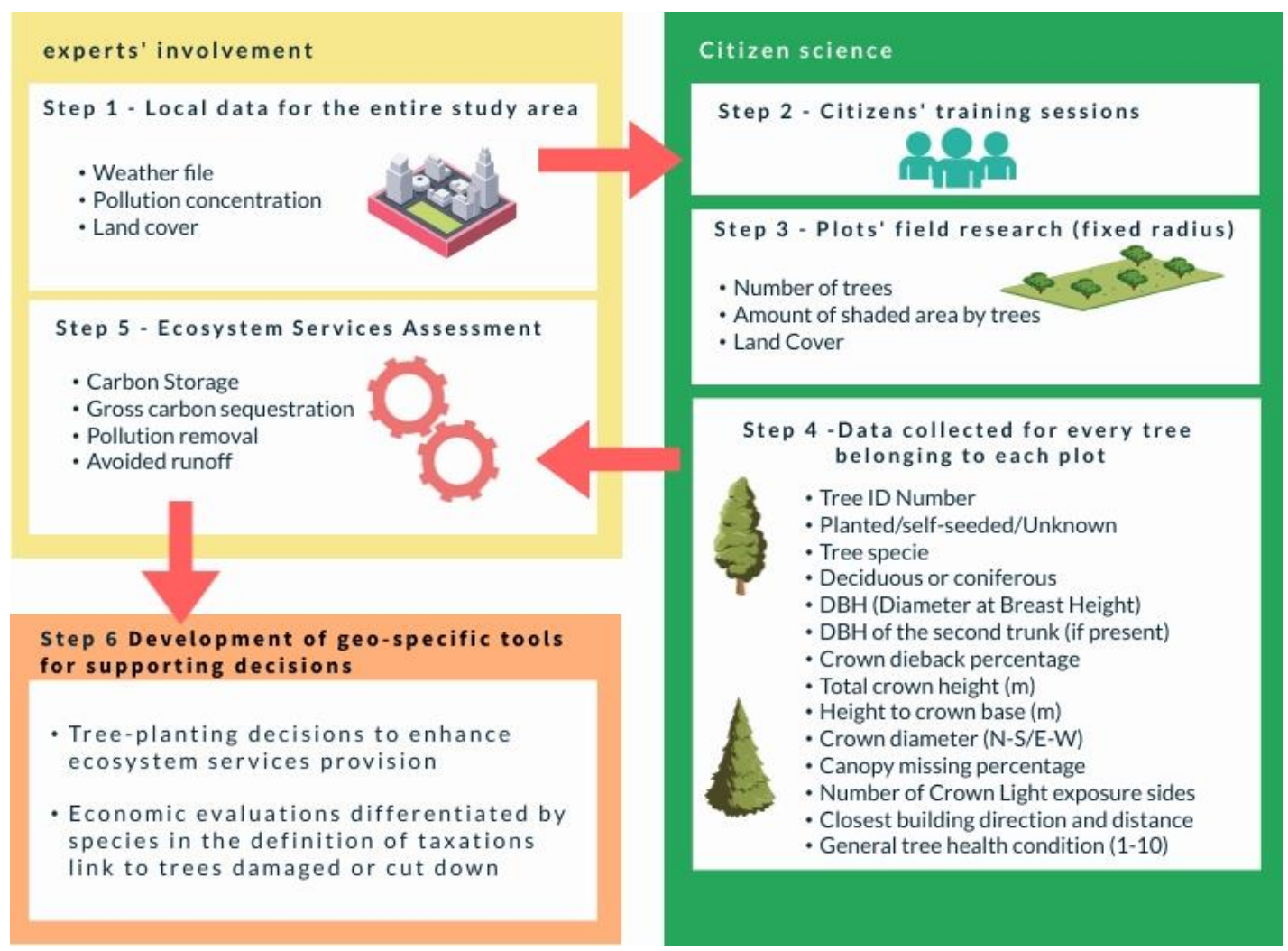

Figure 2. Methodology flowchart.

(1) i-Tree Eco requires, as input, local environmental data (weather file, pollution concentration, and land cover) regarding the study area. Hourly meteorological data were obtained by the Decentralized Meteorological and Hydrological Functional center of the Umbria Region [48]. They refer to the meteorological station nearest to the study area. Local air pollution data were provided by the European Environment Agency [47].

(2) The method uses six training meetings to enhance the empowerment of neighborhood residents involved in field data collection: (i) What can urban trees do for me? Concept of ecosystem services, 2 hours training / (ii) What can you do for our urban trees? Reflections about spatial and management needs of trees for healthy growth in an urban context, 2 hours training. (iii) Observing the characteristic of urban trees and their environment. The method develops three sheets (Supplementary Materials A) dedicated to data collection regarding the whole plot, trees, and shrubs. We explained the rules for their use during this meeting, $2 \mathrm{~h}$. (iv) Visual evaluation of urban trees' health, 2 hours training. (v) Field tests with experts. During this meeting, participants tested their ability in data collection helped by experts, 4 hours training (vi) Discussion about the main problems in surveys filled by citizens, 2 hours training

A forest engineer and an agronomist held the course in the local community headquarter called Pro Ponte association. Fifty people participated in the training course and half of them in the field collection. The activity was also communicated to all citizens through an article published in a local magazine.

(3) The whole surface of the study area is 475.5 ha. To facilitate the data collection for homogeneous urban contexts, i-Tree Eco suggests randomly selecting plots inside the study area to perform field research. We selected 100 randomly located 0.4 ha plots, using a software function developed to this aim (Figure 3). 


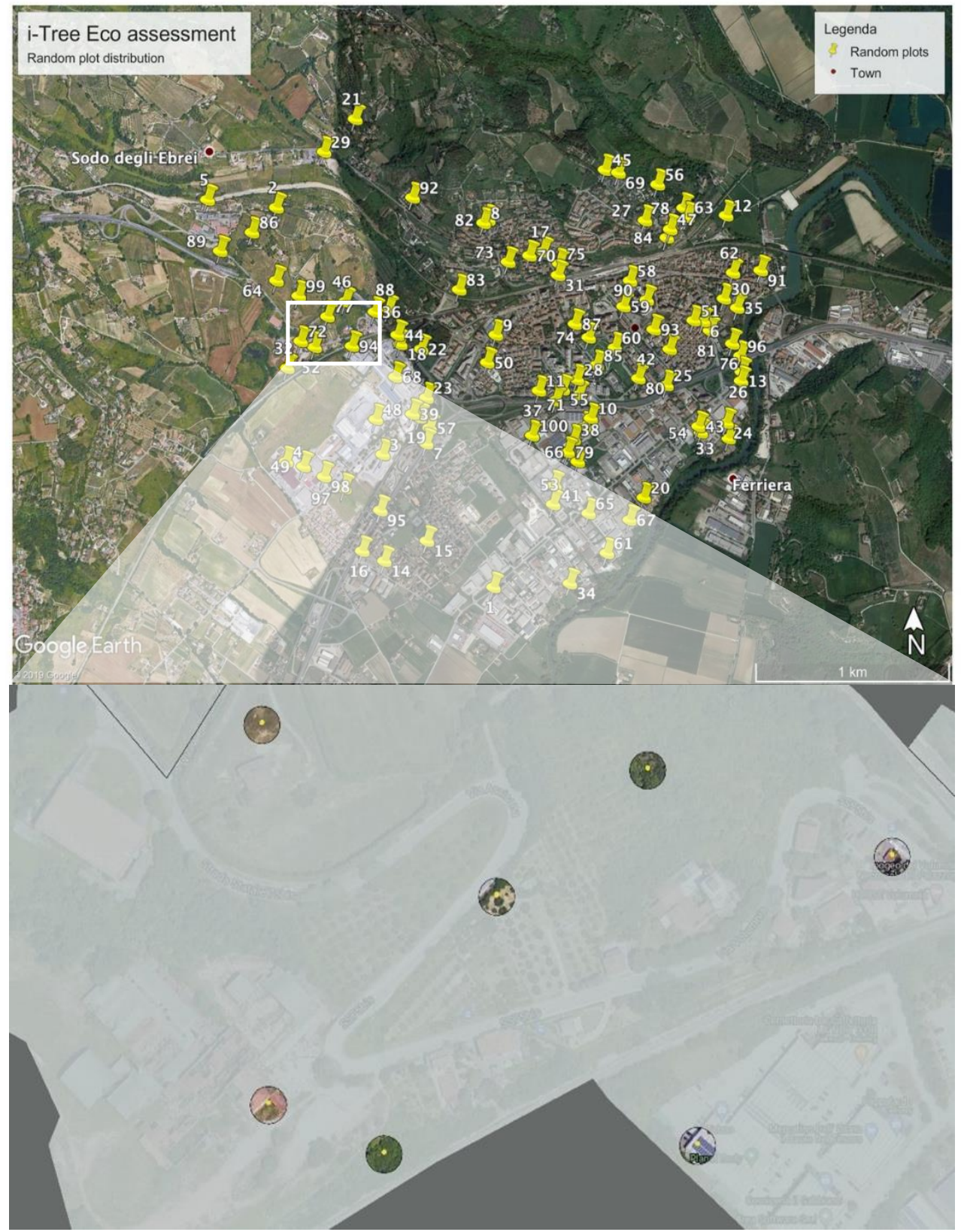

Figure 3. Waypoints for the 100 random plots generated by i-Tree Eco for collecting field data. The zoom shows an example of seven plots.

(4) Plot locations were transferred to the Google Maps mobile application and used by the field data collectors. In August-October 2019, citizens collected coordinates, number of trees, tree cover ground percentage, and land use (Supplementary Materials A, Sheet 1). For every tree belonging to the plot, we trained people to collect a dedicated sheet with these contents (Supplementary Materials A, Sheet 2): tree ID number, planted/selfseeded/unknown, tree species, deciduous or coniferous (in case the species was not identifiable) type, diameter at breast height $(\mathrm{DBH}, \mathrm{cm})$, crown dieback percentage, total crown height $(\mathrm{m})$, height to crown base, crown diameter (N-S/E-W), canopy missing percentage, number of crown light exposure sides, closest building direction and distance (meter and sexagesimal degrees), and general tree health condition (1 to 10). A manual hypsometer and/or the mobile app Distance Meter released by My Mobile Tools Dev were used to estimate trees' height. In some cases, the trees' height was measured empirically by comparing the detector height with objects of known size on the site (fences, buildings, walls, etc.). To identify the species, a dichotomous botanic key was adopted. During the last 
training meeting, the main difficulty that emerged from citizens concerned species identification. During the meeting, we decided with citizens to use the smartphone app Pl@ntNet. Pl@ntNet is a mobile app that allows users to identify plants by merely photographing them with the smartphone's camera and then comparing the photo with a gallery of plants already identified by the community of users. The canopy area of trees was assessed using measurements of crown dimensions and the percentage of crown canopy missing. All field data were collected during the leaf-on season to assess tree canopies accurately. Furthermore, we asked participants to also collect data regarding shrub species, total height (m), the percentage in the volume of the species on the total of shrubs present in the plot, and general health conditions (Supplementary Materials A, Sheet 3).

(5) The characteristic of the urban forest collected during Step 4, and the local environmental data (step 1) were input into i-Tree Eco to assess the ecosystem services provided by the inventoried trees (annual pollution removal by trees: ozone, sulfur dioxide, nitrogen dioxide, carbon monoxide, and particulate matter less than 2.5 microns, carbon storage, annual sequestration, and avoided runoff).

i-Tree Eco uses multiple equations to evaluate every ecosystem service [31,49-51]. To estimate avoided runoff, the software uses hourly rain data and the characteristic of trees in several equations that calculate evapotranspiration and water interception by tree leaves [52]. Rain is also crucial in setting the periods of no-leaf suspension in pollution removal estimates [31,36]. In fact, during precipitation events, the accumulated $\mathrm{PM}_{2.5}$ is assumed to be washed off to the ground surface depending upon the magnitude of the precipitation event, modifying deposition velocity in variable quantities [53]. Air temperature data are also essential because temperature affects leaf stomatal opening, which is fundamental in the flux of pollutants, $\mathrm{CO}_{2}$, and other gases between the air and the leaf $[34,54]$. Wind tends to resuspend the particulate matter from the leaves' surface, so $\mathrm{PM}_{2.5}$ is again spread in the air [36]. Windspeed influences the portion of particulate matter resuspension, so a resuspension percentage is applied to the pollution removal estimate according to windspeed [53]. Solar radiation, used as photosynthetically active radiation, is specific for study area location and contributes to pollution removal and carbon sequestration by leaves [54]. Then, i-Tree Eco allows for using the results of inventoried trees in random plots to estimate the ecosystem services provided by the urban greenery inside the whole study area.

(6) As a tool to support tree planting decisions, the method develops a list with performance values in ecosystem services provision differentiated by tree species. We selected adult and healthy trees from the inventoried ones and assessed their average performance to implement this list. Then, we developed two easy macros in Excel to support municipalities in urban green system design and management. (i) The first macro is helpful in green area design. The macro requests the required ecosystem service in the studied area as an input file. It then outputs a list of tree species belonging to the class with higher performance in providing the requested ecosystem service. For every ecosystem service, the method divides the dispersion between tree performance values into five classes with homogeneous width (tree species belonging to Class 1 have the higher performance, while tree species belonging to Class 5 have the lowest one).

(ii) The second macro is helpful in the definition of rules of taxation linked to tree damage or cut down. The macro requests as an input file the species of the tree that is damaged and/or that must be removed following private projects. Then, based on the class of structural value in which it falls, it helps define its value. Economic value was determined for the following ecosystem services: carbon storage, carbon sequestration, air pollution removal, and avoided runoff. Because there are no accurate local data, pollution removal values were estimated based on European median externality values [55] and Ben MAP regression equations [51] that incorporate user-defined population estimates in 2010; values are then converted to local currency. Prices were EUR 1100 per metric ton for carbon monoxide, EUR 9253 per metric ton for ozone, EUR 1382 per metric ton for nitrogen dioxide, EUR 503 per metric ton for sulfur dioxide, and EUR 321,227 per metric ton for 
$\mathrm{PM}_{2.5}$. Estimates for carbon storage and sequestration are based on the carbon value for the United States in 2015 [56] and converted to Euros for EUR 161 per metric ton. The value of avoided runoff was based on the national average value for the United States in $2005[57,58]$ converted to Euros, and it was estimated as EUR 1.90 per $\mathrm{m}^{3}$.

\section{Results}

The tree cover percentage in the neighborhood is around 30\%. The total area of the plots is $47,549 \mathrm{~m}^{2}$. We inventoried 373 trees, so the resulting tree density of the site is 78.44 trees per ha.

The studied trees belong to 57 species. The most common species are Olea europaea L. (9.9\%), Pinus pinea L. (6.4\%), and Laurus nobilis L. (6.2\%) (Figure 4).

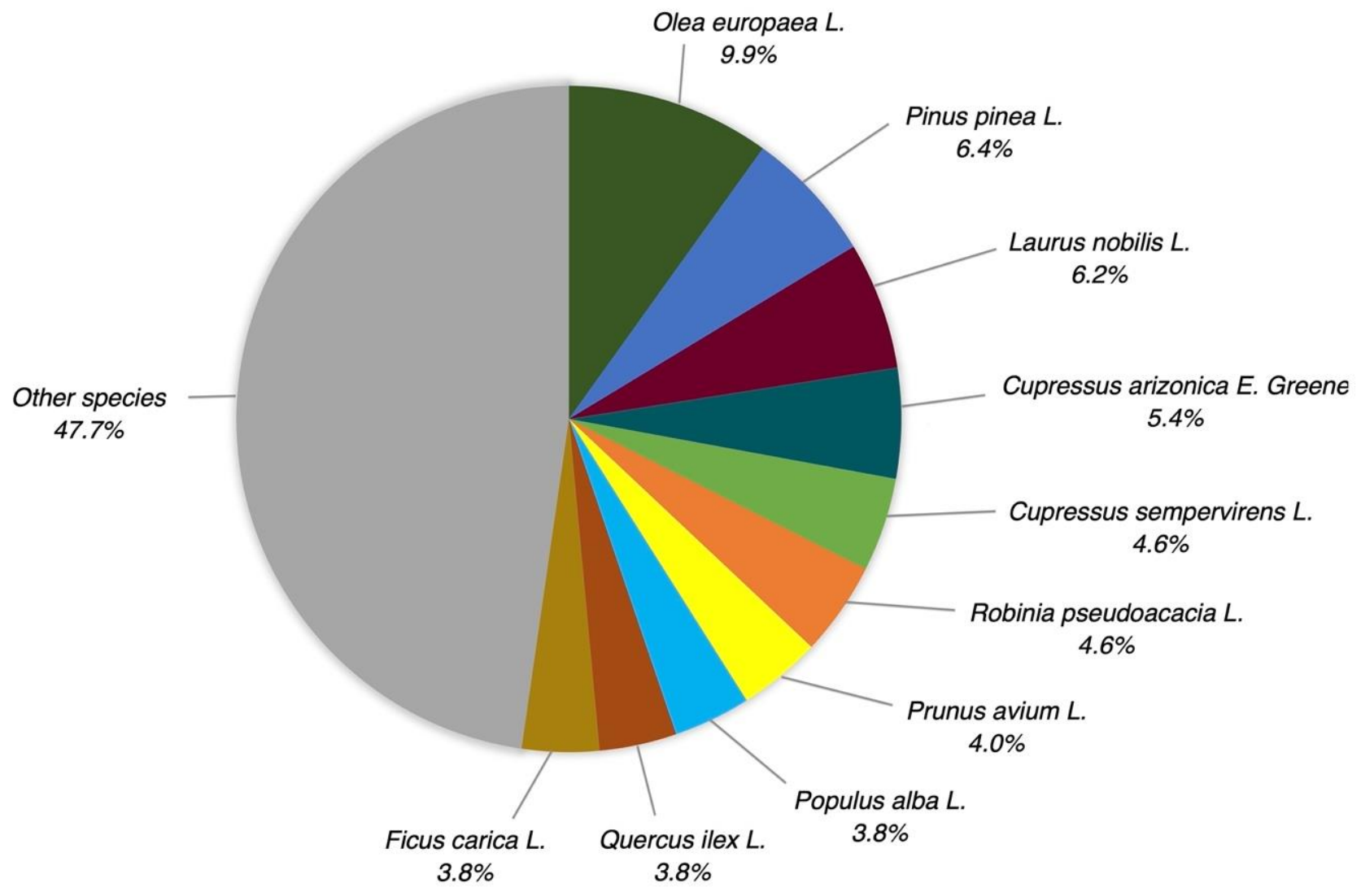

Figure 4. Inventoried trees. Tree species composition.

The majority (around 70\%) of the trees are less than $30.5 \mathrm{~cm} \mathrm{DBH}$. The most common species have $>50 \%$ of their trees with DBH less than 30.5, except for Pinus pinea L., Cupressus arizonica E. Greene, Cupressus sempervirens L., and Populus alba L., which have more large trees (Figure 5). During the field research, researchers and citizens also analyzed the shrubs. Supplementary Materials B (Sheet 2) reports the complete list of the 82 species (57 trees and 25 shrubs). The dominant species in terms of leaf area are two shrubs, Hedera helix L. and Rubus ulmifolius Schott., followed by several tree species. 


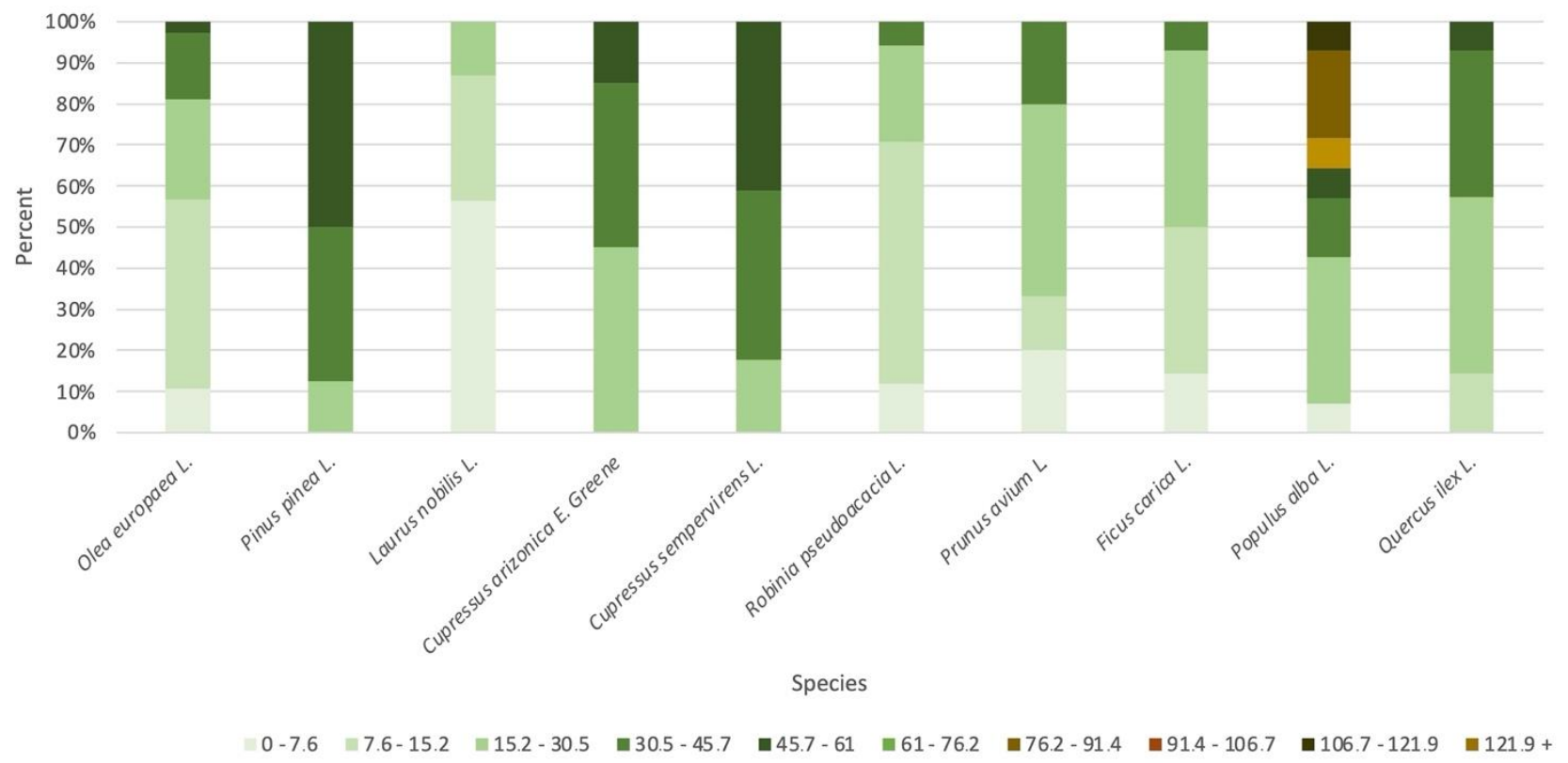

Figure 5. Top 10 species and their percentage distribution by diameter class (DBH-stem diameter at $1.37 \mathrm{~m})$.

Ecosystem Services Assessment and Development of Species-Specific List to Support Decisions in Tree-Planting

The inventoried 373 trees (Supplementary Materials B, Sheet 1) removed $46.2 \mathrm{~kg}$ of air pollution $\left(\mathrm{O}_{3}, \mathrm{CO}, \mathrm{NO}_{2}, \mathrm{PM}_{2.5}\right.$, and $\left.\mathrm{SO}_{2}\right)$ in 2019 , with an associated value of EUR 748 . Gross sequestration by studied trees is $2635 \mathrm{~kg}$ per year with an associated value of EUR 423, while trees have stored 63,806 kg of carbon (EUR 10,252). Populus alba L. has the best performance in carbon storage and sequestration (approximately 18\% of the total carbon stored and $14.7 \%$ of all sequestered carbon) of the sampled species. The inventoried trees have reduced runoff by $88 \mathrm{~m}^{3}$ in 2019, with an associated value of EUR 169. In total, the 373 trees allow yearly saving of EUR 1291. Then, we have used i-Tree Eco to estimate the ecosystem services provided by the whole urban forest of the study area (Supplementary Materials B, Sheet 3.) Overall, i-Tree Eco estimated in the study area 40,680 trees (Standard Error $17 \%, \pm 6920$ trees). The urban forest removed an estimated 6.46 metric tons of air pollution $\left(\mathrm{O}_{3}, \mathrm{CO}, \mathrm{NO}_{2}, \mathrm{PM}_{2.5}\right.$, and $\left.\mathrm{SO}_{2}\right)$ in 2019 , with an associated value of EUR 111,000. Pollution removal is most significant for ozone (Figure 6), with 5 metric tons removed for a value of EUR 46,000.

Trees and shrubs' removal of $\mathrm{PM}_{2.5}$ pollution is worth EUR 63,300, in the study area, which is 197 metric kilograms. In 2019, trees emitted an estimated 4.6 metric tons of volatile organic compounds (VOCs) (3.251 metric tons of isoprene and 1.322 metric tons of monoterpenes). Fifty percent of the urban forest's VOC emissions were from Populus alba L. and Quercus pubescens Willd.

The gross sequestration by urban forest was 287.2 metric tons per year with an associated value of EUR 46,100 (Figure 7). Net carbon sequestration in the urban forest is about 243.7 metric tons. Trees are estimated to store 6960 metric tons of carbon (EUR 1.12 million). Populus alba L. stores and sequesters the most carbon (approximately $18 \%$ of the total carbon stored and $14.7 \%$ of all sequestered carbon) of the sampled species. 


\section{Pollution removal}

6

हू

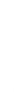

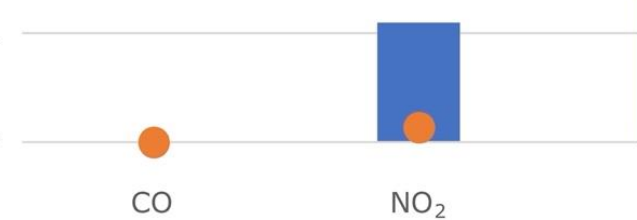

$\mathrm{O}_{3}$

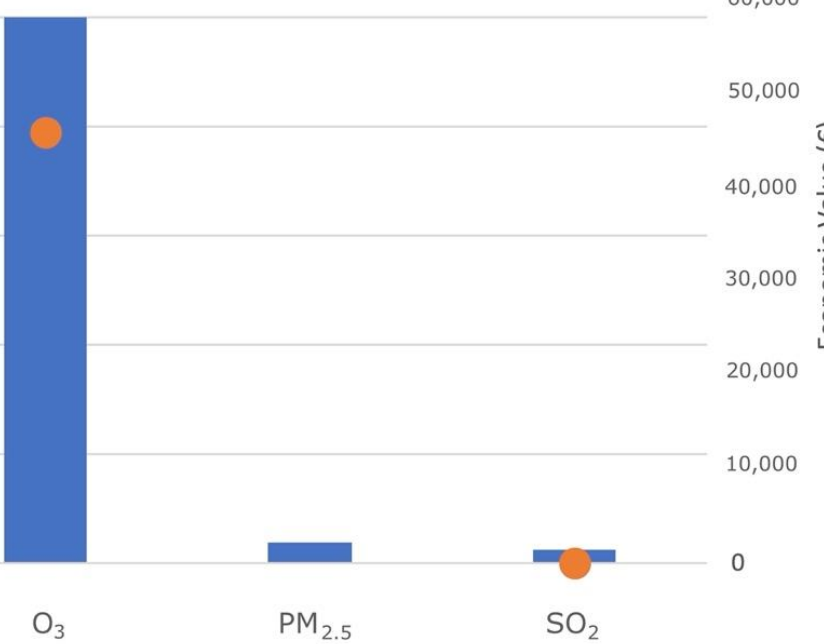

- Pollution Removed (metric ton) (bars)

Economic Value (€) (points)

70,000

60,000

0000

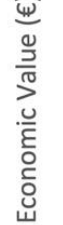

000

Figure 6. Annual pollution removal (bars) and economic value (points) by the urban forest.

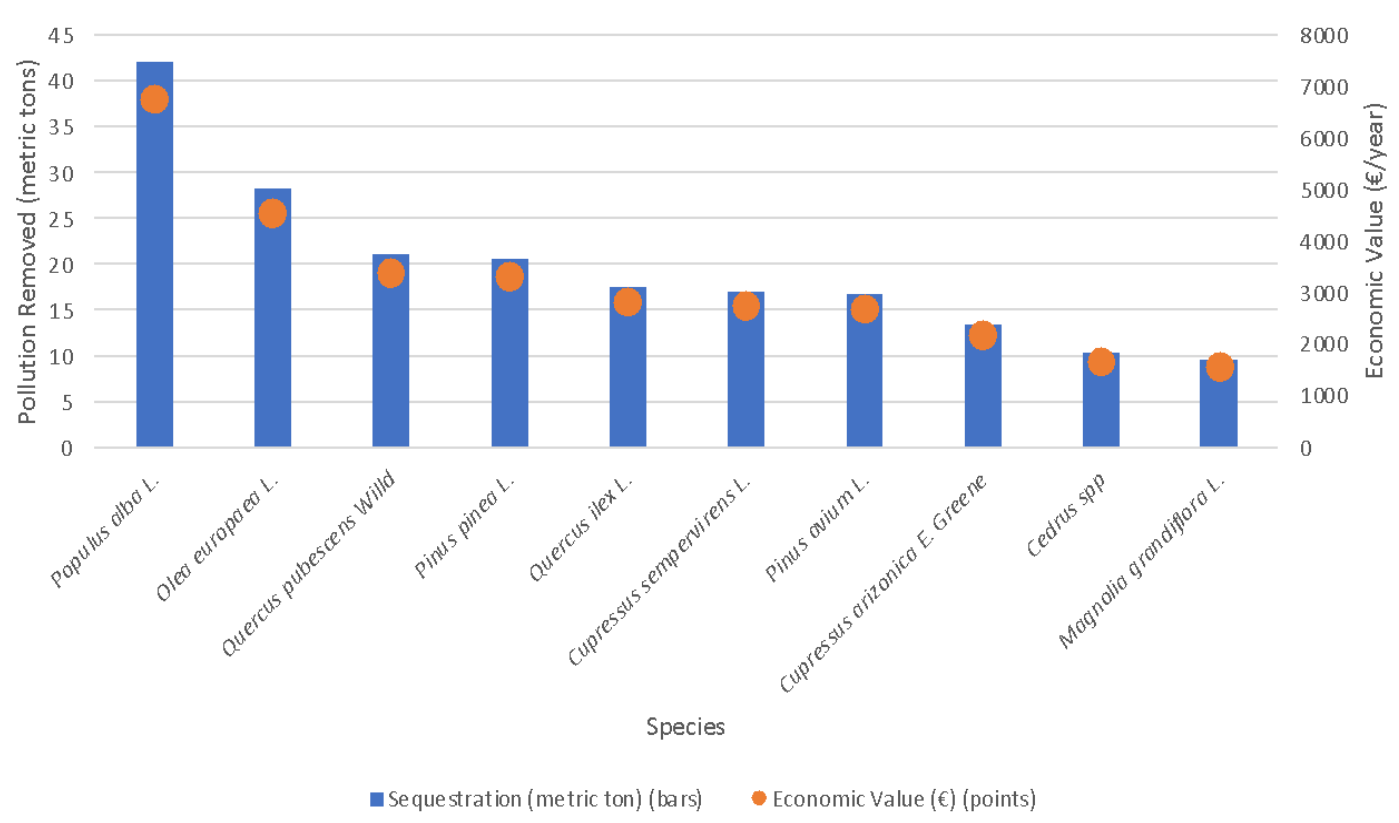

Figure 7. Estimated annual gross carbon sequestration (bars) and economic value (points) for urban tree species with the most significant sequestration.

Urban forest reduced runoff by $12,300 \mathrm{~m}^{3}$ in 2019 , with an associated value of EUR 23,000. In total, the urban forest in the study area has an economic value of 45 million euros.

Starting with differentiated evaluations per inventoried tree (Supplementary Materials B, Sheet 1), we have evaluated ecosystem service provision per tree species in terms of services provided on average by one adult healthy urban tree (Table 2). The table also reports columns referring to the classes of performance. We used the four classes evaluating the ecosystem services to build the first macro, while we used the last class' column for the second macro. Then, we have provided the following table and the two macros to the Local Administration. 
Table 2. Evaluations of the regulating ecosystem services provided by an adult tree in good health status in a densely built-up Mediterranean area, differentiated by the 57 species studied. The species are listed in alphabetic order. They rank from Class 1 (excellent performance in providing the studied ecosystem service) to Class 5 (low performance).

\begin{tabular}{|c|c|c|c|c|c|c|c|c|c|c|}
\hline \multirow[t]{2}{*}{ Species } & \multicolumn{2}{|c|}{ Carbon Storage } & \multicolumn{2}{|c|}{$\begin{array}{l}\text { Gross Carbon } \\
\text { Sequestration }\end{array}$} & \multicolumn{2}{|c|}{ Avoided Runoff } & \multicolumn{2}{|c|}{ Pollution Removal } & \multicolumn{2}{|c|}{$\begin{array}{l}\text { Structural } \\
\text { Value }\end{array}$} \\
\hline & Class & (Metric ton) & Class & (Metric ton/yr) & Class & $\left(\mathrm{m}^{3} / \mathrm{yr}\right)$ & Class & (Metric ton/yr) & Class & (EUR) \\
\hline Abies alba Mill. & 5 & $1.04 \times 10^{-1}$ & 5 & $4.60 \times 10^{-3}$ & 5 & $1.70 \times 10^{-1}$ & 5 & $9.17 \times 10^{-5}$ & 5 & 1006 \\
\hline Acacia Mill. & 5 & $4.0 \times 10^{-4}$ & 5 & $2.00 \times 10^{-4}$ & 5 & $6.80 \times 10^{-3}$ & & & 5 & 47 \\
\hline Acer campestre $\mathrm{L}$. & 5 & $3.67 \times 10^{-2}$ & 5 & $2.80 \times 10^{-3}$ & 5 & $5.98 \times 10^{-2}$ & 5 & $3.33 \times 10^{-5}$ & 5 & 171 \\
\hline Acer pseudoplatanus L. & 5 & $8.09 \times 10^{-2}$ & 5 & $5.60 \times 10^{-3}$ & 5 & $1.69 \times 10^{-1}$ & 5 & $9.17 \times 10^{-5}$ & 5 & 854 \\
\hline Acer spp. & 3 & $4.18 \times 10^{-1}$ & & & & & & & & \\
\hline Ailanthus altissima Mill. & 5 & $7.20 \times 10^{-3}$ & 5 & $1.40 \times 10^{-3}$ & 5 & $9.82 \times 10^{-2}$ & 5 & $5.24 \times 10^{-5}$ & 5 & 92 \\
\hline Carpinus betulus L. & 5 & $3.84 \times 10^{-2}$ & 5 & $6.10 \times 10^{-3}$ & 5 & $1.53 \times 10^{-1}$ & 5 & $9.17 \times 10^{-5}$ & 5 & 597 \\
\hline Cedrus spp. & 2 & $5.61 \times 10^{-1}$ & 4 & $1.20 \times 10^{-2}$ & 1 & $9.88 \times 10^{-1}$ & 1 & $5.16 \times 10^{-4}$ & 1 & 4970 \\
\hline Celtis australis $\mathrm{L}$. & 4 & $2.47 \times 10^{-1}$ & 3 & $1.61 \times 10^{-2}$ & 1 & $8.64 \times 10^{-1}$ & 1 & $4.59 \times 10^{-4}$ & 4 & 1689 \\
\hline Cercis siliquastrum $\mathrm{L}$. & 5 & $2.46 \times 10^{-2}$ & 5 & $2.80 \times 10^{-3}$ & 5 & $1.19 \times 10^{-1}$ & 5 & $9.17 \times 10^{-5}$ & 5 & 471 \\
\hline Citrus limon (L.) Osbeck & 5 & $6.00 \times 10^{-4}$ & 5 & $3.00 \times 10^{-4}$ & 5 & $1.08 \times 10^{-2}$ & & & 5 & 47 \\
\hline Corylus avellana $\mathrm{L}$. & 5 & $3.06 \times 10^{-2}$ & 5 & $2.50 \times 10^{-3}$ & 5 & $1.71 \times 10^{-1}$ & 5 & $9.17 \times 10^{-5}$ & 5 & 508 \\
\hline Crataegus monogyna Jacq. & 5 & $1.28 \times 10^{-2}$ & 5 & $2.50 \times 10^{-3}$ & 5 & $1.44 \times 10^{-1}$ & 5 & $6.88 \times 10^{-5}$ & 5 & 213 \\
\hline $\begin{array}{l}\text { Cupressus arizonica } \mathrm{E} . \\
\text { Greene }\end{array}$ & 4 & $1.95 \times 10^{-1}$ & 4 & $6.20 \times 10^{-3}$ & 3 & $4.32 \times 10^{-1}$ & 3 & $2.25 \times 10^{-4}$ & 4 & 1755 \\
\hline Cupressus sempervirens $\mathrm{L}$. & 4 & $2.84 \times 10^{-1}$ & 4 & $9.20 \times 10^{-3}$ & 4 & $3.43 \times 10^{-1}$ & 4 & $1.78 \times 10^{-4}$ & 3 & 2592 \\
\hline Cycas revoluta Thunb. & 5 & $9.40 \times 10^{-3}$ & 5 & $1.00 \times 10^{-4}$ & 4 & $3.13 \times 10^{-1}$ & 4 & $1.84 \times 10^{-4}$ & 5 & 369 \\
\hline $\begin{array}{l}\text { Eriobotrya japonica } \\
\text { (Thunb.) Lindl. }\end{array}$ & 5 & $7.09 \times 10^{-2}$ & 5 & $6.00 \times 10^{-3}$ & 5 & $1.46 \times 10^{-1}$ & 5 & $6.88 \times 10^{-5}$ & 5 & 736 \\
\hline Ficus carica L. & 5 & $1.06 \times 10^{-1}$ & 4 & $6.20 \times 10^{-3}$ & 5 & $1.96 \times 10^{-1}$ & 5 & $1.05 \times 10^{-4}$ & 5 & 788 \\
\hline Ilex aquifolium $\mathrm{L}$. & 5 & $4.40 \times 10^{-2}$ & 5 & $3.90 \times 10^{-3}$ & 5 & $7.86 \times 10^{-2}$ & & & 5 & 567 \\
\hline Juglans regia L. & 4 & $2.04 \times 10^{-1}$ & 4 & $1.19 \times 10^{-2}$ & 2 & $7.28 \times 10^{-1}$ & 2 & $3.85 \times 10^{-4}$ & 5 & 890 \\
\hline Lagerstroemia indica $\mathrm{L}$. & 5 & $3.97 \times 10^{-2}$ & 5 & $4.10 \times 10^{-3}$ & 5 & $6.14 \times 10^{-2}$ & 5 & $3.44 \times 10^{-5}$ & 5 & 521 \\
\hline Larix decidua Mill. & 5 & $1.21 \times 10^{-1}$ & 5 & $5.00 \times 10^{-3}$ & 1 & $8.01 \times 10^{-1}$ & 1 & $4.59 \times 10^{-4}$ & 4 & 1457 \\
\hline Laurus nobilis L. & 5 & $2.25 \times 10^{-2}$ & 5 & $2.50 \times 10^{-3}$ & 5 & $7.24 \times 10^{-2}$ & 5 & $3.59 \times 10^{-5}$ & 5 & 262 \\
\hline Ligustrum lucidum Aiton & 5 & $6.98 \times 10^{-2}$ & 5 & $3.00 \times 10^{-3}$ & 5 & $4.85 \times 10^{-2}$ & 5 & $2.29 \times 10^{-5}$ & 5 & 365 \\
\hline Ligustrum sinense Lour. & 5 & $2.46 \times 10^{-3}$ & 5 & $1.83 \times 10^{-4}$ & 5 & $1.31 \times 10^{-2}$ & & & 5 & 59 \\
\hline Ligustrum vulgare L. & 5 & $1.10 \times 10^{-3}$ & 5 & $3.00 \times 10^{-4}$ & 5 & $1.11 \times 10^{-2}$ & & & 5 & 31 \\
\hline Magnolia grandiflora $\mathrm{L}$. & 4 & $2.10 \times 10^{-1}$ & 4 & $9.90 \times 10^{-3}$ & 4 & $2.44 \times 10^{-1}$ & 4 & $1.22 \times 10^{-4}$ & 4 & 1330 \\
\hline Magnolia liliiflora Desr. & 5 & $2.85 \times 10^{-2}$ & 5 & $3.00 \times 10^{-3}$ & 5 & $6.49 \times 10^{-2}$ & 5 & $4.59 \times 10^{-5}$ & 5 & 440 \\
\hline Malus domestica Borkh. & 5 & $1.28 \times 10^{-2}$ & 5 & $3.20 \times 10^{-3}$ & 5 & $8.59 \times 10^{-2}$ & & & 5 & 171 \\
\hline Morus nigra L. & 5 & $1.42 \times 10^{-1}$ & 4 & $7.80 \times 10^{-3}$ & 4 & $2.06 \times 10^{-1}$ & 5 & $9.17 \times 10^{-5}$ & 5 & 695 \\
\hline Nerium oleander L. & 5 & $4.30 \times 10^{-3}$ & 5 & $7.00 \times 10^{-4}$ & 5 & $3.24 \times 10^{-2}$ & 5 & $1.31 \times 10^{-5}$ & 5 & 87 \\
\hline Olea europaea L. & 5 & $1.26 \times 10^{-1}$ & 4 & $7.00 \times 10^{-3}$ & 5 & $9.27 \times 10^{-2}$ & 5 & $4.71 \times 10^{-5}$ & 5 & 814 \\
\hline Ostrya carpinifolia Scop. & 5 & $1.87 \times 10^{-2}$ & 5 & $2.40 \times 10^{-3}$ & 5 & $4.99 \times 10^{-2}$ & & & 5 & 449 \\
\hline Picea abies (L.) H. Karst. & 4 & $2.03 \times 10^{-1}$ & 4 & $9.70 \times 10^{-3}$ & 3 & $4.84 \times 10^{-1}$ & 3 & $2.57 \times 10^{-4}$ & 4 & 1534 \\
\hline Pinus halepensis Mill. & 3 & $3.77 \times 10^{-1}$ & 4 & $9.10 \times 10^{-3}$ & 2 & $7.79 \times 10^{-1}$ & 2 & $3.67 \times 10^{-4}$ & 2 & 3055 \\
\hline Pinus nigra J.F. Arnold & 5 & $8.19 \times 10^{-2}$ & 5 & $3.20 \times 10^{-3}$ & 4 & $3.49 \times 10^{-1}$ & 4 & $1.84 \times 10^{-4}$ & 5 & 981 \\
\hline Pinus pinea L. & 4 & $2.59 \times 10^{-1}$ & 4 & $7.90 \times 10^{-3}$ & 4 & $3.57 \times 10^{-1}$ & 4 & $1.87 \times 10^{-4}$ & 3 & 2647 \\
\hline Pinus sylvestris L. & 4 & $2.99 \times 10^{-1}$ & 5 & $5.70 \times 10^{-3}$ & 4 & $2.12 \times 10^{-1}$ & 4 & $1.22 \times 10^{-4}$ & 3 & 2680 \\
\hline $\begin{array}{l}\text { Platanus } x \text { acerifolia } \\
\text { (Aiton) Willd. }\end{array}$ & 2 & $6.16 \times 10^{-1}$ & 1 & $3.02 \times 10^{-2}$ & 2 & $6.48 \times 10^{-1}$ & 2 & $3.67 \times 10^{-4}$ & 2 & 3377 \\
\hline Populus alba L. & 1 & $8.18 \times 10^{-1}$ & 1 & $2.76 \times 10^{-2}$ & 2 & $6.34 \times 10^{-1}$ & 2 & $3.27 \times 10^{-4}$ & 3 & 2088 \\
\hline Prunus amygdalus Batsch & 5 & $4.98 \times 10^{-2}$ & 5 & $4.60 \times 10^{-3}$ & 4 & $2.63 \times 10^{-1}$ & 5 & $9.17 \times 10^{-5}$ & 5 & 533 \\
\hline Prunus armeniaca L. & 5 & $9.69 \times 10^{-2}$ & 4 & $6.20 \times 10^{-3}$ & 5 & $1.27 \times 10^{-1}$ & 5 & $6.88 \times 10^{-5}$ & 5 & 547 \\
\hline Prunus avium L. & 5 & $1.39 \times 10^{-1}$ & 4 & $1.03 \times 10^{-2}$ & 5 & $1.64 \times 10^{-1}$ & 5 & $8.56 \times 10^{-5}$ & 5 & 787 \\
\hline Prunus cerasifera Ehrh. & 5 & $1.85 \times 10^{-2}$ & 5 & $2.70 \times 10^{-3}$ & 5 & $6.19 \times 10^{-2}$ & & & 5 & 245 \\
\hline Prunus cerasus L. & 5 & $4.00 \times 10^{-4}$ & 5 & $3.00 \times 10^{-4}$ & 5 & $6.20 \times 10^{-3}$ & & & 5 & 36 \\
\hline Prunus domestica L. & 5 & $1.37 \times 10^{-1}$ & 5 & $5.30 \times 10^{-3}$ & 5 & $5.39 \times 10^{-2}$ & 5 & $3.06 \times 10^{-5}$ & 5 & 511 \\
\hline Prunus persica (L.) Batsch & 5 & $1.00 \times 10^{-2}$ & 5 & $1.80 \times 10^{-3}$ & 5 & $4.07 \times 10^{-2}$ & 5 & $1.83 \times 10^{-5}$ & 5 & 168 \\
\hline Punica granatum L. & 5 & $1.06 \times 10^{-2}$ & 5 & $1.10 \times 10^{-3}$ & 5 & $2.63 \times 10^{-2}$ & 5 & $2.29 \times 10^{-5}$ & 5 & 177 \\
\hline Pyrus communis L. & 5 & $2.83 \times 10^{-2}$ & 5 & $5.00 \times 10^{-3}$ & 5 & $1.17 \times 10^{-1}$ & 5 & $9.17 \times 10^{-5}$ & 5 & 533 \\
\hline Quercus ilex L. & 4 & $2.98 \times 10^{-1}$ & 4 & $1.15 \times 10^{-2}$ & 4 & $2.32 \times 10^{-1}$ & 4 & $1.18 \times 10^{-4}$ & 4 & 1763 \\
\hline Quercus pubescens Willd. & 1 & $6.74 \times 10^{-1}$ & 2 & $2.16 \times 10^{-2}$ & 3 & $5.42 \times 10^{-1}$ & 3 & $2.85 \times 10^{-4}$ & 4 & 1886 \\
\hline Quercus robur $\mathrm{L}$. & 5 & $4.41 \times 10^{-2}$ & 5 & $4.10 \times 10^{-3}$ & 5 & $7.62 \times 10^{-2}$ & & & 5 & 605 \\
\hline Rhamnus alaternus $\mathrm{L}$. & 5 & $2.40 \times 10^{-3}$ & 5 & $1.30 \times 10^{-3}$ & 5 & $4.20 \times 10^{-3}$ & & & 5 & 64 \\
\hline Robinia pseudoacacia $\mathrm{L}$. & 5 & $6.40 \times 10^{-2}$ & 5 & $4.30 \times 10^{-3}$ & 4 & $2.02 \times 10^{-1}$ & 5 & $1.08 \times 10^{-4}$ & 5 & 303 \\
\hline Thuja L. & 5 & $3.57 \times 10^{-2}$ & 5 & $1.40 \times 10^{-3}$ & 5 & $1.69 \times 10^{-1}$ & 5 & $8.51 \times 10^{-5}$ & 5 & 757 \\
\hline Tilia cordata Mill. & 5 & $4.69 \times 10^{-2}$ & 5 & $5.70 \times 10^{-3}$ & 4 & $2.64 \times 10^{-1}$ & 5 & $9.17 \times 10^{-5}$ & 4 & 1098 \\
\hline $\begin{array}{l}\text { Washingtonia robusta } \\
\text { H.Wendl. }\end{array}$ & 5 & $3.40 \times 10^{-3}$ & 5 & $1.00 \times 10^{-4}$ & 5 & $3.73 \times 10^{-2}$ & 5 & $3.06 \times 10^{-5}$ & 5 & 844 \\
\hline
\end{tabular}

\section{Discussion}

\subsection{Efficiency in Citizens Involvement in Field Research to Build Tree Inventories}

Italian municipalities need to improve the efficiency of urban tree inventories. In this regard, this paper used the input data requested by i-Tree Eco to develop surveys that are usable during the field research (Supplementary Materials A). The paper showed that these 
surveys are fillable even by non-expert users. Indeed, i-Tree Eco requests as input data field research easy to perform. They do not require instrumental evaluations or the collection of contaminable information. Anyway, there is the need to provide basic training to recognize the tree and shrub species and do a visual assessment. The case study showed how citizens, after six training sessions, can collect the data autonomously. The resulting main issue was linked to species recognition, overcome by installing the Pl@ntNet app.

Citizen involvement in urban green system studies is not a novelty. Several studies directly involve citizens to evaluate their perception linked to the ecosystem services provided by trees in an urban environment [15], their recreational value [59], or their willingness to pay for ecosystem services [60].

Our results show as citizens' participation should also be carefully considered for realizing the urban tree inventories since it provides a cost-effective method for obtaining field data. Furthermore, their involvement has provided the raising of the awareness toward the urban forest and understanding the crucial values of trees in the urban context by the citizens.

\subsection{Tree Species Composition in the Urban Forests of Dense Built-Up Mediterranean Cities and Ecosystem Services Assessment}

The study area is a neighborhood of Perugia. This municipality has its tree inventory ongoing (in 2022). Respecting the Italian law requirement [21,22], Perugia, like the other Italian municipalities, is building its municipal tree inventory only for public green areas (mostly urban parks) and along the main public roads [23]. The public online municipal dataset, which refers to the current state of the tree inventory, reports 48,261 trees (year 2019) [61]. The most common tree species are Pinus pinea L. (8\%), Tilia spp. (7\%), Cupressus sempervirens L. (6\%), Quercus ilex L. (5\%), Populus spp. (3.2\%), Robinia pseudoacacia L. (3.2\%); Aesculus hippocastanum L. (3\%), Olea Europea L. (2.6\%), Cupressus arizonica E. Greene (2.5\%), and Acer spp. (2.3\%). Unfortunately, this dataset does not report data necessary to use i-Tree Eco (Supplementary Materials A). Nevertheless, it is interesting to compare this urban forest composition with our results. A total of $70 \%$ of our inventoried trees are in private areas, $25 \%$ in private gardens, and only $6 \%$ in urban public parks. The dominant species in terms of the number of trees are Olea Europaea L. (9.9\%), Pinus pinea L. (6.4\%), and Laurus nobilis L. $(6.2 \%)$ (Figure 4$)$. Our results show that Italian municipal tree inventories do not adequately represent the urban forest in dense built-up Mediterranean cities. Indeed, they report only trees in public green areas. In contrast, in built-up areas, trees are mostly located in private plots and private gardens or have marginal functions linked to vegetation (i.e., trees at the entrance to a public building). It is essential to evaluate urban forests' composition in public and private spaces to define their role in ecosystem services provision [24,25,62].

At the same time, local administrations struggle in building municipal tree inventories, even limited to public areas. In this regard, they could successfully involve citizens, as discussed in the previous section. In private areas, the simulation tool of i-Tree Eco could be beneficial, reducing the field research to random plots and using their results to simulate the performance of the whole. Our study reports results for 373 inventoried trees (Supplementary Materials B, Sheet 1), and then we simulated the urban forest composition for the whole study area (Supplementary Materials B, Sheet 3; Figures 6 and 7). Our simulation has a standard error of $17 \%$ due to the low number of plots used to perform the field research. Nevertheless, we used the simulation's results only to provide urban planners with approximative quantification using identifiable boundaries (the studied neighborhood). The local Administration could increase the area covered by the field research to decrease the standard error [31].

Looking more in-depth at the tree species composition, our results show the most representative tree species in our case study is Olea Europea L. Indeed, even if Olea Europea L. is a productive tree, in the urban contexts of central and southern Italy, it is a traditional tree also used with an ornamental aim, a common trait of various Mediterranean contexts such as Greece and Spain. As with most tree species primarily used for production purposes, Olea 


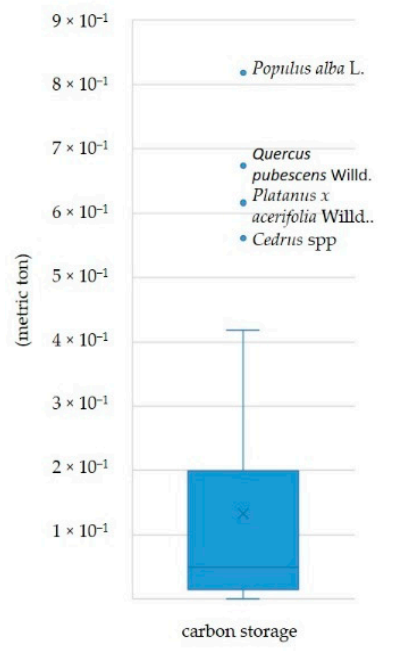

Europea L. has many varieties with different structural characteristics (e.g., the leaves size and diameter) and, consequently, variable performances linked to differentiated regulating services. i -Tree Eco does not consider the variety but only the species. In our case, the varieties are Frantoio, Leccino, Dolce Agogia, San Felice, Pendolino, and Maurino.

This consideration outlines the geo-specificity of these inventories in ecosystem services assessment. Figure 8 shows the distribution between the resulting values among tree species for our study area.
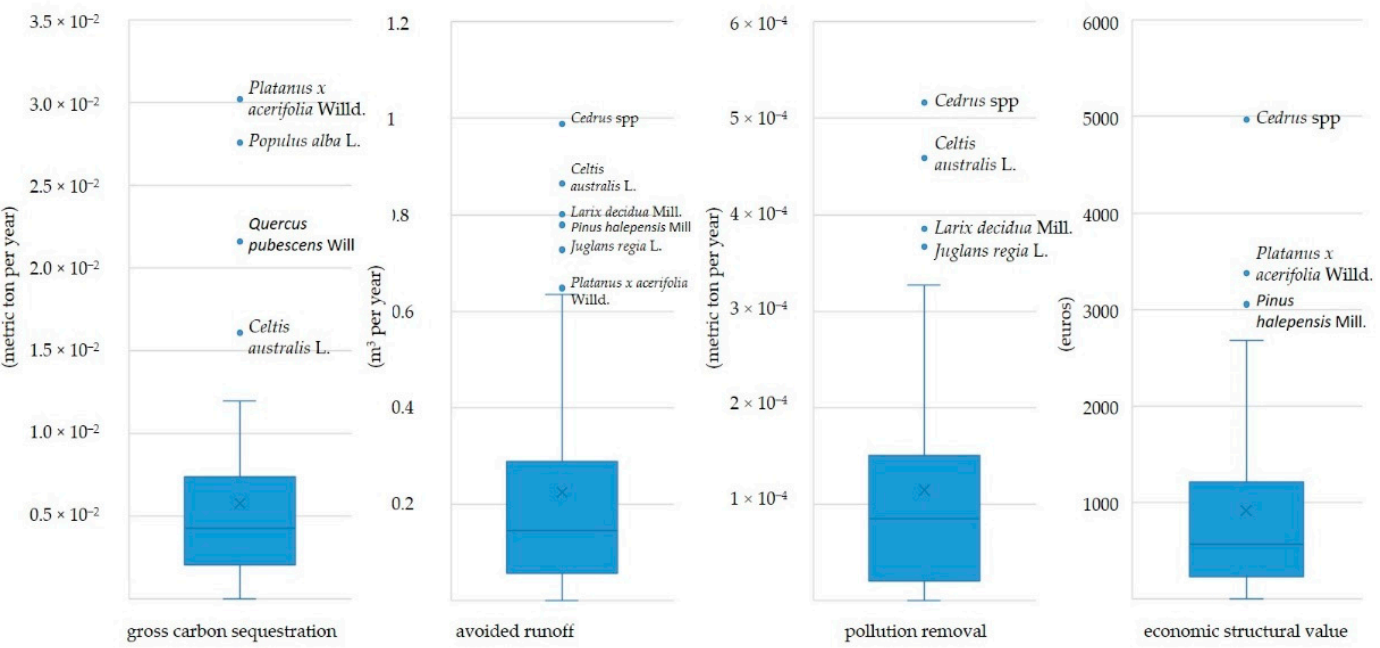

Figure 8. Box-plots showing the distribution between values of performance in providing ecosystem services of inventoried tree species.

In the case study, the tree species with the higher performance in carbon storage are Populus alba L. (0.8184 metric ton per tree), Quercus pubescens Willd. (0.6740), Platanus $x$ acerifolia Mill. (0.6161), and Cedrus spp. (0.5614). Other studies in Italy [34] confirm these species as a very effective carbon sink. Platanus $x$ acerifolia Mill., Populus alba L., Quercus pubescens Willd., and Celtis australis L. are the best for carbon sequestration. The tree species with an amount of yearly avoided runoff higher than $0.7 \mathrm{~m}^{3}$ per tree are Cedrus spp. (0.9882 $\mathrm{m}^{3}$ /year), Celtis australis L. (0.8643), Larix decidua Mill. (0.8007), Pinus halepensis Mill. (0.7789), and Juglans regia L. (0.7278). There is not much literature on the ranking of the best-performing trees for avoided runoff in urban areas, so new studies should be carried out from this perspective. Indeed, many studies report overall evaluations for the urban forest $[7,19]$ and are not differentiated by species. Trees with the best performance in pollution removal are Cedrus spp., Celtis australis L., and Larix decidua Mill, which remove more than $0.3 \times 10^{-4}$ metric tons of pollutants from the air yearly per tree. Thanks to their wide leaf area and roughness, they are excellent in pollution removal. The coniferous trees such as Cedrus spp. and Larix decidua Mill. also perform well thanks to the annual persistence of leaves on the plant [63], particularly for $\mathrm{PM}_{2.5}$ [64]. These results depend on the composition of the inventoried species, climate characteristics, and urban morphology.

\subsection{Tool Supporting Decisions for Enhancing Ecosystem Services Provided by Urban Greenery}

As discussed by Acosta et al. [8], the success of ecosystem service provision depends largely on the decisions made by urban planners and politicians. Thus, user-friendly tools to support their choices are fundamental.

Table 2 shows the evaluations of the regulating ecosystem services provided by an adult tree in good health status in a densely built-up Mediterranean area, differentiated by the 57 species studied. Using this list, we developed a tool composed of two Excel macros.

The first macro (the result of Step 6.1 of the method) requests as the input file the demanded ecosystem service and outputs the more performant tree species. In this way, the tree species choices could be based on the specific ecosystem service that the decision-maker needs to emphasize in each green area. For example, in urban areas subject to frequent 
flooding, urban designers will look for trees helping in stormwater management; along streets with high levels of traffic, they will look for trees helping pollution removal. Indeed, the concentration of pollutants varies along the roads or inside the parks [36], such as rainwater runoff and the consequent flooding problems [65]. At the same time, the need for carbon storage is not linked to localization specifications. Current mobile sensors could help administrations make timely assessments of the demand for ecosystem services in their contexts. Furthermore, the first macro could be used by a local administrator to encourage choices that enhance environmental benefits for the citizens. Municipalities could georeference the areas with frequent flooding then provide built-up potentialities increase to the residents, also transferable to other areas, if they plant inside their propriety trees belonging to Class 1 or 2 of "runoff avoided." For Italian municipalities, it is usual to establish rules to transfer development rights inside their municipal plans linked to specific aims [65]. In the case of the Municipality of Perugia, the current implementation rules of its Urban Plan [66] offer an increase in built-up potentialities to citizens who implement a retrofit intervention in their buildings to improve their energy efficiency.

The second macro (the result of Step 6.2) requests, as the input, the tree species file. It provides, as a result, an economic evaluation of the species based on the average characteristics in the study area (state of health and dimension) of trees of the same species and on their performance in providing ecosystem services. This macro is valid in the definition of rules of taxation linked to tree damage or cut down (i.e., a citizen has the permit to cut down a private tree to realize a new building). The economic values refer to the years 2005-2007. Nevertheless, they are helpful to distribute the tree species in five classes of differentiated monetary value. The minimum value is 31 euro for Citrus limon (L.) Osbeck, and the maximum value is 4970 euro for Cedrus spp. The low weight of Citrus limon (L.) Osbeck is because the trees in the study area were not in good health (the climate of the study area does not allow to grow this species permanently outdoor through the year). Indeed, they should be kept in greenhouses during winter.

The two macros offer an easy tool usable by the end-users (e.g., urban planners, decision-makers, etc.) once the tree inventory and the i-Tree Eco evaluation are fully developed. Anyway, it is essential to define some limitations of the developed tool.

First, the study focuses on carbon storage, carbon sequestration, pollution removal, and runoff avoided, not considering other ecosystem services provided by the urban forest, such as cultural services [14,67] humidity control, temperature control [8], and many others. Other scholars developed tools for using ecosystem services assessment in urban planning, such as the one designed by Acosta et al. [8] for urban heat island mitigation by an urban forest, or the one developed by Menconi et al. [67] to enhance the cultural ecosystem services' provision by urban parks. For local administrators, it would be essential to integrate these tools to achieve an overall awareness of the value of the urban forests.

Second, this could be a helpful tool in tree planting decisions, which goes alongside other data that could be used to filter tree species. These data refer to the characteristics of the tree, such as light requirement, its undesirable qualities (i.e., high mortality rates and allergenicity), resistance to breakage [18], and the characteristics of the urban area object of the design (shape, dimension, and function of the area) [36].

Finally, the tool helps in tree species selection, but the overall design of the green area influences its performance. In this regard, Tahvonen [19] described how to integrate water and vegetation better to enhance stormwater management, scaling up from pilot-scale garden designs to habitats at the block scale.

\section{Conclusions}

In recent sector legislation, Italian municipalities were identified as the keepers of urban greenery, despite suffering from a lack of funds and staff and often administering historic densely built-up cities where it is harder to plan and execute appropriate interventions. Therefore, local administrators require decision-making tools to evaluate and compare design alternatives and, thus, make more informed choices. The paper develops 
an easy tool to compare values of urban trees clearly and transparently and therefore allow, more competently, to make the best choices to increase the overall positive impact on the urban forest ecosystem.

We also evaluated the ecosystem services provided by the urban forest of a neighborhood of a densely built-up city of central Italy. Starting from geo-referred local climate data, land use, and field research to evaluate the local urban forest structure, we used i-Tree Eco to perform the evaluation. Our results show that the Italian Municipal tree inventories do not adequately represent the urban forest in dense built-up Mediterranean cities. Indeed, they report only trees in public green areas. In built-up areas, trees are primarily located in private plots, private gardens, or public open spaces with marginal functions linked to vegetation.

Finally, our method involved citizens in field research and shows that tree inventories can benefit from their engagement. The proposed method offers an interesting testimony to this effect and pushes us to design new applications to other areas and other cities to strengthen its validation.

Supplementary Materials: The following are available online at https:/ /www.mdpi.com/article/10.3 390/su14031684/s1. A. Data Collection Sheets for Field Research; B. The Dataset Containing the Results of the Field Research and the Ecosystem Services Estimation by i-Tree Eco.

Author Contributions: Conceptualization, L.R., A.B., and D.G.; methodology, L.R., D.J.N., and D.G.; software, L.R., M.E.M., and D.J.N.; validation, L.R. and D.J.N.; formal analysis, L.R. and D.J.N.; investigation, L.R. and A.B.; data curation, L.R., M.E.M., and D.G.; writing-original draft preparation, L.R. and M.E.M.; writing-review and editing, A.B., D.J.N., M.E.M., and D.G.; visualization, L.R., M.E.M., and D.G.; supervision, M.E.M., D.G., and D.J.N.; project administration, D.G. Luca Rossi (L.R.), Maria Elena Menconi (M.E.M.), David Grohmann (D.G.), Antonio Brunori (A.B.), David J. Nowak (D.J.N.). All authors have read and agreed to the published version of the manuscript.

Funding: This research received no external funding.

Institutional Review Board Statement: Not applicable.

Informed Consent Statement: Not applicable.

Conflicts of Interest: The authors declare no conflict of interest.

\section{References}

1. United Nations. Department of Economic and Social Affairs. Population dynamics. Available online: https://population.un.org/ wup / (accessed on 20 September 2021).

2. Millennium Ecosystem Assessment. Conceptual Framezork. Ecosystems and Human Well-Being; Island Press: Washington, DC, USA, 2005; pp. 25-36. ISBN 978-1559633901.

3. Nowak, D.J.; Crane, D.E. The Urban Forest Effects (UFORE) Model: Quantifying urban forest structure and functions. In Integrated Tools for Natural Resources Inventories in the 21st Century. Gen. Tech. Rep. NC-212; Hansen, M., Burk, T., Eds.; Department of Agriculture, Forest Service, North Central Forest Experiment Station: St. Paul, MN, USA, 2000; pp. 714-720.

4. Wang, B.; Liu, Z.; Mei, Y.; Li, W. Assessment of ecosystem service quality and its correlation with landscape patterns in Haidian District, Beijing. Int. J. Environ. Res. Public Health 2019, 16, 1248. [CrossRef] [PubMed]

5. Camps-Calvet, M.; Langemeyer, J.; Calvet-Mir, L.; Gómez-Baggethund, E. Ecosystem services provided by urban gardens in Barcelona, Spain: Insights for policy and planning. Environ. Sci. Policy 2016, 62, 14-23. [CrossRef]

6. Lin, B.B.; Egerer, M.H.; Liere, H.; Jha, S.; Bichier, P.; Philpott, S.M. Local-and landscape-scale land cover affects microclimate and water use in urban gardens. Sci. Total Environ. 2018, 610, 570-575. [CrossRef] [PubMed]

7. Ferrini, F.; Fini, A.; Mori, J.; Gori, A. Role of Vegetation as a Mitigating Factor in the Urban Context. Sustainability 2020, $12,4247$. [CrossRef]

8. Acosta, M.; Vahdatikhaki, F.; Santos, J.; Hammad, A.; Dorée, A.G. How to bring UHI to the urban planning table? A data-driven modeling approach. Sustain. Cities Soc. 2021, 71, 102948. [CrossRef]

9. Elliott, R.M.; Motzny, A.E.; Majd, S.; Chavez, F.J.V.; Laimer, D.; Orlove, B.S.; Culligan, P.J. Identifying linkages between urban green infrastructure and ecosystem services using an expert opinion methodology. Ambio 2020, 49, 569-583. [CrossRef] [PubMed]

10. Schäffler, A.; Swilling, M. Valuing green infrastructure in an urban environment under pressure-The Johannesburg case. Ecol. Econ. 2013, 86, 246-257. [CrossRef]

11. Nowak, D.J.; Greenfield, E.J. Recent changes in global urban tree and impervious cover. Urban For. Urban Green. 2020, $49,126638$. [CrossRef] 
12. Cimburova, Z.; Barton, D.N. The potential of geospatial analysis and Bayesian networks to enable i-Tree Eco assessment of existing tree inventories. Urban For. Urban Green. 2020, 55, 126801. [CrossRef]

13. Dobbs, C.; Kendal, D.; Nitschke, C.R. Multiple ecosystem services and disservices of the urban forest establishing their connections with landscape structure and sociodemographics. Ecol. Indic. 2014, 43, 44-55. [CrossRef]

14. Menconi, M.E.; Palazzoni, L.; Grohmann, D. Core themes for an urban green systems thinker: A review of complexity management in provisioning cultural ecosystem services. Urban For. Urban Green. 2021, 65, 127355. [CrossRef]

15. Menconi, M.E.; Heland, L.; Grohmann, D. Learning from the gardeners of the oldest community garden in Seattle: Resilience explained through ecosystem services analysis. Urban For. Urban Green. 2020, 56, 126878. [CrossRef]

16. Campbell, L.K. Getting farming on the agenda: Planning, policymaking, and governance practices of urban agriculture in New York City. Urban For. Urban Green. 2016, 19, 295-305. [CrossRef]

17. Matasov, V.; Marchesini, L.B.; Yaroslavtsev, A.; Sala, G.; Fareeva, O.; Seregin, I.; Castaldi, S.; Vasenev, V.; Valentini, R. IoT monitoring of urban tree ecosystem services: Possibilities and challenges. Forests 2020, 11, 775. [CrossRef]

18. Werbin, Z.R.; Heidari, L.; Buckley, S.; Brochu, P.; Butler, L.J.; Connolly, C.; Houttuijn Bloemendaal, L.; McCabe, T.D.; Miller, T.K.; Hutyra, L.R. A tree-planting decision support tool for urban heat mitigation. PLoS ONE 2020, 15, e0224959. [CrossRef]

19. Tahvonen, O. Scalable green Infrastructure-The case of domestic private gardens in Vuores, Finland. Sustainability 2018, 10, 4571. [CrossRef]

20. Fox, W.; Dwivedi, P.; Lowe, R.C.; Welch, S.; Fuller, M. Estimating Carbon Stock of Live Trees Located on the Main Campus of the University of Georgia. J. For. 2020, 118, 457-465. [CrossRef]

21. Italian Ministry of Ecological Transition. L. 10/2013. Available online: https://www.mite.gov.it/sites/default/files/archivio/ normativa/legge_14_01_2013_10.pdf (accessed on 5 September 2021).

22. Italian Official Gazette. D.M. 63/2020. Available online: https://www.mite.gov.it/sites/default/files/archivio/allegati/GPP/20 20/guri_dm_63_del_2020_verde_002.pdf (accessed on 5 September 2021).

23. ISTAT. Urban Environment. Urban Greenery: Table 11.1 (Availability of Urban Green Area Per Person). Available online: https://www.istat.it/it/archivio/264816 (accessed on 5 September 2021).

24. Biernacka, M.; Kronenberg, J. Classification of institutional barriers affecting the availability, accessibility and attractiveness of urban green spaces. Urban For. Urban Green. 2018, 36, 22-33. [CrossRef]

25. Cilliers, S.; Cilliers, J.; Lubbe, R.; Siebert, S. Ecosystem services of urban green spaces in African countries-perspectives and challenges. Urban Ecosyst. 2013, 16, 681-702. [CrossRef]

26. Villa, F.; Bagstad, K.J.; Voigt, B.; Johnson, G.W.; Portela, R.; Honzák, M.; Batker, D. A Methodology for Adaptable and Robust Ecosystem Services Assessment. PLoS ONE 2014, 9, e91001. [CrossRef]

27. Prybutok, S.; Newman, G.; Atoba, K.; Sansom, G.; Tao, Z. Combining Co\$ting Nature and Suitability Modeling to Identify High Flood Risk Areas in Need of Nature-Based Services. Land 2021, 10, 853. [CrossRef] [PubMed]

28. Jackson, B.; Pagella, T.; Sinclair, F.; Orellana, B.; Henshaw, A.; Reynolds, B.; Mcintyre, N.; Wheater, H.; Eycott, A. Polyscape: A GIS mapping framework providing efficient and spatially explicit landscape-scale valuation of multiple ecosystem services. Landsc. Urban Plan. 2013, 112, 74-88. [CrossRef]

29. Hamel, P.; Guerry, A.D.; Polasky, S.; Han, B.; Douglass, J.A.; Hamann, M.; Janke, B.; Kuiper, J.J.; Levrel, H.; Liu, H.; et al. Mapping the benefits of nature in cities with the InVEST software. Npj Urban Sustain. 2021, 1, 25. [CrossRef]

30. Mulligan, M. Climate change and food-water supply from Africa's drylands: Local impacts and teleconnections through global commodity flows. Int. J. Water Resour. Dev. 2015, 31, 450-460. [CrossRef]

31. Nowak, D.J. Understanding i-Tree: Summary of programs and methods. In General Technical Reports NRS-200; Department of Agriculture, Forest Service, Northern Research Station: Madison, WI, USA, 2020; 100p.

32. Yarnvudhi, A.; Leksungnoen, N.; Tor-Ngern, P.; Premashthira, A.; Thinkampheang, S.; Hermhuk, S. Evaluation of Regulating and Provisioning Services Provided by a Park Designed to Be Resilient to Climate Change in Bangkok, Thailand. Sustainability 2021, 13, 13624. [CrossRef]

33. Zanzi, A.; Andreotti, F.; Vaglia, V.; Alali, S.; Orlando, F.; Bocchi, S. Forecasting Agroforestry Ecosystem Services Provision in Urban Regeneration Projects: Experiences and Perspectives from Milan. Sustainability 2021, 13, 2434. [CrossRef]

34. Baraldi, R.; Chieco, C.; Neri, L.; Facini, O.; Rapparini, F.; Morrone, L.; Rotondi, A.; Carriero, G. An integrated study on air mitigation potential of urban vegetation: From a multi-trait approach to modeling. Urban For. Urban Green. 2019, 41, 127-138. [CrossRef]

35. Riondato, E.; Pilla, F.; Sarkar Basu, A.; Basu, B. Investigating the effect of trees on urban quality in Dublin by combining air monitoring with i-Tree Eco model. Sustain. Cities Soc. 2020, 61, 102356. [CrossRef]

36. Szkop, Z. Evaluating the sensitivity of the i-Tree Eco pollution model to different pollution data inputs: A case study from Warsaw, Poland. Urban For. Urban Green. 2020, 55, 126859. [CrossRef]

37. Su, T.H.; Lin, C.S.; Lin, J.C.; Liu, C.P. Dry deposition of particulate matter and its associated soluble ions on five broadleaved species in Taichung, central Taiwan. Sci. Total Environ. 2021, 753, 141788. [CrossRef]

38. Pace, R.; Guidolotti, G.; Baldacchini, C.; Pallozzi, E.; Grote, R.; Nowak, D.J.; Calfapietra, C. Comparing i-Tree Eco Estimates of Particulate Matter Deposition with Leaf and Canopy Measurements in an Urban Mediterranean Holm Oak Forest. Environ. Sci. Technol. 2021, 55, 6613-6622. [CrossRef] [PubMed] 
39. Nowak, D.J.; Crane, D.E.; Stevens, J.C.; Hoehn, R.E.; Walton, J.T.; Bond, J. A ground-based method of assessing urban forest structure and ecosystem services. Aboriculture Urban For. 2008, 34, 347-358. [CrossRef]

40. Berland, A. Urban tree growth models fo two nearby cities show notable differences. Urban Ecosyst. 2020, $23,1253-1261$. [CrossRef]

41. Lin, J.; Kroll, C.N.; Nowak, D.J. An uncertainty framework for i-Tree eco: A comparative study of 15 cities across the United States. Urban For. Urban Green. 2021, 60, 127062. [CrossRef]

42. Millward, A.A.; Sabir, S. Benefits of a forested urban park: What is the value of Allan Gardens to the city of Toronto, Canada? Landsc. Urban Plan. 2011, 100, 177-188. [CrossRef]

43. Endreny, T.; Santagata, R.; Perna, A.; Stefano, C.D.; Rallo, R.F.; Ulgiati, S. Implementing and managing urban forests: A much needed conservation strategy to increase ecosystem services and urban well-being. Ecol. Model. 2017, 360, 328-335. [CrossRef]

44. Barò, F.; Calderòn-Argelich, A.; Langemeyer, J.; Connolly, J.J.T. Under one canopy? Assessing the distributional environmental justice implications of street tree benefits in Barcelona. Environ. Sci. Policy 2019, 102, 54-56. [CrossRef]

45. Cariñanos, P.; Marinangeli, F. An uptaded proposal of the Potential Allergenicity of 150 ornamental trees and shrubs in Medirettanean Cities. Urban For. Urban Green. 2021, 63, 127218. [CrossRef]

46. Demographic Statistic ISTAT. Available online: http:/ / demo.istat.it/bilmens / index.php?anno=2020\&lingua=ita (accessed on 5 September 2021).

47. European Environment Agency. Climatic Data and Pollution. Available online: https://www.eea.europa.eu/themes/air/exploreair-pollution-data (accessed on 5 September 2021).

48. Umbria Region, Hydrographic Regional Service. Available online: https://www.regione.umbria.it/ambiente/servizioidrografico (accessed on 5 September 2021).

49. Coville, R.; Endreny, T.; Nowak, D.J. Modeling the impact of urban trees on hydrology. In Forest-Water Interactions. Ecological Studies (Analysis and Synthesis); Levia, D., Carlyle-Moses, D., Iida, S., Michalzik, B., Nanko, K., Tischer, A., Eds.; Springer: Cham, Switzerland, 2020; Volume 240, pp. 459-487.

50. Nowak, D.J.; Greenfield, E.J.; Hoehn, R.; LaPoint, E. Carbon storage and sequestration by trees in urban and community areas of the United States. Environ. Pollut. 2013, 178, 229-236. [CrossRef]

51. Nowak, D.J.; Hirabayashi, S.; Bodine, A.; Greenfield, E.J. Tree and forest effects on air quality and human health in the United States. Environ. Pollut. 2014, 193, 119-129. [CrossRef]

52. Hirabayashi, S. i-Tree Eco Precipitation Interception Model Descriptions. 2015. Available online: http:/ /www.itreetools.org/eco/ resources/iTree_Eco_Precipitation_Interception_Model_Descriptions.pdf (accessed on 10 December 2021).

53. Nowak, D.J.; Hirabayashi, S.; Bodine, A.; Hoehn, R. Modeled PM 2.5 removal by trees in ten U.S. cities and associated health effects. Environ. Pollut. 2013, 178, 395-402. [CrossRef] [PubMed]

54. Baldocchi, D.D.; Hicks, B.B.; Camera, P. A canopy stomatal resistance model for gaseous deposition to vegetated surfaces. Atmos. Environ. 1987, 21, 91-101. [CrossRef]

55. Van Essen, H.; Schroten, A.; Otten, M.; Sutter, D.; Schreyer, C.; Zandonella, R.; Maibach, M.; Doll, C. External Costs of Transport In Europe; CE Delft: Delft, Netherlands, 2011.

56. U.S. Environmental Protection Agency. The Social Cost of Carbon. 2015. Available online: http://www.epa.gov/climatechange/ EPActivities/economics/scc.html (accessed on 10 December 2021).

57. McPherson, E.G.; Simpson, J.R. Carbon Dioxide Reduction through Urban Forestry: Guidelines for Professional and Volunteer Tree Planters; General Technical Report PSW-171; U.S. Department of Agriculture, Forest Service, Pacific Southwest Research Station: Albany, CA, USA, 1999.

58. McPherson, E.G.; Simpson, J.R.; Peper, P.J.; Crowell, A.M.N.; Xiao, Q. Northern California Coast Community Tree Guide: Benefits, Costs, and Strategic Planting; General Technical Report PSW-GTR-228; U.S. Department of Agriculture, Forest Service, Pacific Southwest Research Station: Albany, CA, USA, 2010.

59. Sacchelli, S.; Fabbrizzi, S.; Geri, F.; Ciolli, M. Place-based policy-making and community security: A decision support system for integrated planning of urban ecosystem services and disservices. Green Energy Technol. 2018, 0, 95-104. [CrossRef]

60. He, B.J.; Zhao, D.; Xiong, K.; Qi, J.; Ulpiani, G.; Pignatta, G.; Prasad, D.; Jones, P. A framework for addressing urban heat challenges and associated adaptive behavior by the public and the issue of willingness to pay for heat resilient infrastructure in Chongqing, China. Sustain. Cities Soc. 2021, 75, 103361. [CrossRef]

61. Perugia. Tree Balance 2014-2018. Available online: https://www.lifeclivutspringames.education/wp-content/uploads/2020/04/ BilancioArboreoPerugia.pdf (accessed on 5 September 2021).

62. Shackleton, C.M.; Blair, A.; De Lacy, P.; Kaoma, H.; Mugwagwa, N.; Dalu, M.T.; Walton, W. How important is green infrastructure in small and medium-sized towns? Lessons from South Africa. Landsc. Urban Plan. 2018, 180, 273-281. [CrossRef]

63. Dasch, M.J. Measurement of dry deposition to surface in deciduous and pine canopies. Environ. Pollut. 1987, 44, 261-277. [CrossRef]

64. Wu, J.; Wang, Y.; Qiu, S.; Peng, J. Using the modified i-Tree Eco model to quantify air pollution removal by urban vegetation. Sci. Totale Environ. 2019, 688, 673-683. [CrossRef]

65. Martinico, F.; La Rosa, D.; Privitera, R. Green oriented urban development for urban ecosystem services provision in a medium sized city in southern Italy. IForest 2014, 7, 385-395. [CrossRef] 
66. Municipalty of Perugia, Urban Plan. Implementation Rules. 2021. Available online: https:/ /www.comune.perugia.it/resources/ prg/TUNA.pdf (accessed on 5 September 2021).

67. Menconi, M.E.; Sipone, A.; Grohmann, D. Complex Systems Thinking Approach to Urban Greenery to Provide CommunityTailored Solutions and Enhance the Provision of Cultural Ecosystem Services. Sustainability 2021, 13, 11787. [CrossRef] 